\title{
NIGER BASIN AUTHORITY
}

As a result of a special meeting of the Niger River Commission (established in 1964), to discuss the revitalizing and restructuring of the organization to improve its efficiency, the Niger Basin Authority was established in 1980. Its responsibilities cover the harmonization and co-ordination of national development policies; the formulation of the general development policy of the Basin; the elaboration and implementation of an integrated development plan of the Basin; the initiation and monitoring of an orderly and rational regional policy for the utilization of the waters of the Niger River; the design and conduct of studies, researches and surveys; the formulation of plans, the construction, exploitation and maintenance of structure, and the elaboration of projects.

Members. Benin, Burkina Faso, Cameroon, Chad, Côte d'Ivoire, Guinea, Mali, Niger, Nigeria.

Official languages: English, French.

Website: http://www.abn.ne

Headquarters: BP 729, Niamey, Niger.

Executive Secretary: Muhammad Bello Tuga.

\section{SOUTHERN AFRICAN DEVELOPMENT COMMUNITY (SADC)}

The Southern African Development Co-ordination Conference (SADCC), the precursor of the Southern African Development Community (SADC), was formed in Lusaka, Zambia on 1 April 1980, following the adoption of the Lusaka Declaration-Southern Africa: Towards Economic Liberation-by the nine founding member states.

Members. The nine founder member countries were Angola, Botswana, Lesotho, Malaŵi, Mozambique, Swaziland, Tanzania, Zambia and Zimbabwe. The Democratic Republic of the Congo, Mauritius, Namibia, the Seychelles and South Africa have since joined. However, the Seychelles left in July 2004. As a result there are now 13 members.

Aims and Activities. SADC's Common Agenda includes the following: the promotion of sustainable and equitable economic growth and socio-economic development that will ensure poverty alleviation with the ultimate objective of its eradication; the promotion of common political values, systems and other shared values that are transmitted through institutions that are democratic, legitimate and effective; and the consolidation and maintenance of democracy, peace and security.

In contrast to the country-based co-ordination of sectoral activities and programmes, SADC has now adopted a more centralized approach through which the 21 sectoral programmes are grouped into four clusters; namely: Trade, Industry, Finance and Investment; Infrastructure and Services; Food, Agriculture, and Natural Resources; Social and Human Development and Special Programmes.

SADC has made significant progress in implementing its integration agenda since the 1992 Treaty came into force. Since then, 23 Protocols to spearhead the sectoral programmes and activities have been signed. The following protocols have entered into force: Immunities and Privileges; Combating Illicit Drug Trafficking; Energy; Transport, Communications and Meteorology; Shared Watercourse Systems; Mining; Trade; Education and Training; Development of Tourism; Health, Wildlife Conservation and Law Enforcement; Tribunal and the Rules of Procedure; Revised Protocol on Shared Watercourses; Amendment Protocol on Trade; Politics, Defense and Security Co-operation; Control of Firearms, Ammunition and Other Related Materials in SADC; Fisheries.

Official languages: English, French, Portuguese. 